\title{
Elefanten i \\ (bede)rummet \\ Raciale forsvindingsnumre, stemningspolitik og idiomatisk diffraktion
}

\section{Af Kirsten Hvenegård-Lassen og Dorthe Staunæs}

\begin{abstract}
The elephant in the room. Racial disappearance acts, mood politics and idiomatic diffraction summarizes a particular way of handling social and cultural problems. It is about social taboos that are affectively charged: even if everybody knows the elephant is there, they ignore it. In this article, we are grappling with disappearance acts related to race and racialization at a white-dominated Danish university. Race is simultaneously there and not there in organizational policies and practices preoccupied with governing diversity. Using a recent debate over 'prayer rooms' in educational institutions, we develop a methodology ('idiomatic diffraction') sensitive towards race and racialization in contexts dominated by whiteness. Leaning on Karen Barad, we argue that diffraction may open up a space from where light can be explored in the shadows of what Sylvia Wynter names 'Man's Project'.
\end{abstract}

\section{KEYWORDS}

Race; affect; diffraction; intersectionality; academia

Kirsten Hvenegård-Lassen er ph.d. og lektor ved Kultur- og Sprogmødestudier, Roskilde Universitet.

Dorthe Staunæs er ph.d. og professor ved Danmarks Institut for Pædagogik og Uddannelse, Aarhus Universitet. 


\section{0}

Køn $i$ akademia-projekt viste, at trods et øget antal kvindekroppe er universitet stadig præget af heteronormative diskurser og patriarkalske strukturer (Højgaard og Søndergaard 2003). I en række poststrukturalistiske og kulturanalytiske analyser af akademisk subjektivering og sociale kategorier var opmærksomheden rettet mod metodologier, der greb aspekter af fravær og forsvinden (ibid.).

Analyserne handlede mestendels om universiteternes vidensproduktion og subjektivering i forhold til netop $k ø n$. Teksterne var ordknappe $\mathrm{i}$ forhold til intersektionelle sammenvævninger af kategorier, der på daværende tidspunkt buldrede løs i engelske og amerikanske kredse (Anthias og YuvalDavies 1992; Brah og Phoenix 2004; Collins 1998; Crenshaw 1991; Lorde 1984/ 2007; Minh-ha 1986/87) og så småt tiltrak sig opmærksomhed i Norden (Lykke 2010; Myong 2009; Mørck 1998; Staunæs 2003; Staunæs og Søndergaard 2006; Søndergaard 2005).

I dag er opmærksomhed på sammenvævninger af sociale kategorier som køn, race, etnicitet, klasse, seksualitet og abilitet stadigt stigende, men også genstand for debat. De mest udfordrende bud kommer fra sort feminisme, queer- og transteorier, post- og dekolonialisme, oprindelige befolkningers ${ }^{1}$ feminisme og hvidhedsstudier. I en dansk samtid henter grupper som det feministiske kollektiv Marronage og studenterorganisationen Front fx inspiration fra disse strømninger. Herfra spørges der til (feminismens) kønskategorier, der ses som altid allerede sammenvævede med det, der tæller som det menneskelige, og derfor også som konstitutivt racialiserede. Som Sylvia Wynter argumenterer for, er 'det menneskelige' en genre, hvis historiske tilblivelse knytter sig til racialisering, og: “(...) Man's Project has provided the global conditions of existence, without being able to realize a universality able to go beyond the limits of its own ethno-class, biohumanist, and therefore liberal modality of universalism" (2006, 163; se også Spillers 1987).

Ontologien i 'Man's Project' er fuld af huller. Afledt af det bliver spørgsmålet: er feminismens kvinde- og kønskategorier altid allerede i udgangspunktet hvide (hooks 1981; Mohanty 2003/2007; Oyewumi 2002/2007)? Der er imidlertid det med hvidheden, at den kan være svær at få greb om - den har det med at tage transparente former og forsvinde (Frankenberg 1993), det gælder måske i særdeleshed i den del af verden, vi lever i: Danmark.

Race er en visuel markør, men kan samtidig ikke begribes gennem visuelle paradigmer udelukkende. Race er altid allerede en materialitet, men som Arun Saldanha (2006) skriver, kan en analyse af materialiteten ikke reduceres til biologi eller natur, idet racialisering altid klistrer kultur og biologi sammen. Race kan begrebssættes som en fortløbende proces, hvorigennem kroppe differentieres og (gen)arrangeres gennem deres 'intra-action' med det socio$ø$ kologiske miljø.

Race er et relationelt frenomen. Race griber og skaber subjekter og kroppe i relationer og fanger på den måde alle. Men race griber og opleves forskelligt (Andreassen og Myong 2017). På hvidhedens side af relationen er der ingen uro, snarere en falden komfortabelt på plads i 'Man's Project' og dermed i farveblindhedens lænestol, der allerede er formet af og til den hvide krop (Ahmed 2006). På den ikke-hvide side af relationen er der derimod sjældent ro og lænestolen trykker. Derfor er det i høj grad fra ikke-hvide positioner, påpegningen af race og racialisering kommer. Andetheden involverer en epistemologisk fordel.

Når artiklen vender blikket mod hvidheden, hviler det på den grundpræmis, at når race er relationelt, så er det også nødvendigt at bearbejde her. Det er nødvendigt at 
fange de måder, hvidhedens dominans udspiller sig på. Hvordan kan vi metodologisk få fat i de måder, race cirkulerer på i en kontekst som vores, hvor den cirkulation hele tiden forsvinder? Der er en elefant $\mathrm{i}$ rummet. Det store dyr minimeres dog til ingenting, til en spøgelsesagtig eksistens, og omgxrdes med tavshed. Selvom alle på sæt og vis ved, at den er der.

Målet er altså en metodologi, der hjælper med at fremmane den institutionaliserede hvidhed, der på hegemonisk vis udstikker rammerne for subjektivering (og styring) på universitetet, men glimrer ved sit fravær, når konkrete sager som eksempelvis curriculum, bederum, morgensang, 'safe spaces' og udklædningskostumer debatteres i medier og/eller behandles i de universitære fora. Med et lidt krøllet fagudtryk benævner vi metodologien idiomatisk diffraktion. $\mathrm{Vi}$ har eksperimenteret os frem til den ad tre veje:

For det første inddrager vi empiri, nemlig en debat fra 2017 om såkaldte 'bederum' (eller som det hedder på Københavns Universitet: retræterum), hvor universitetets daværende rektor udtalte, at debatten udtrykte en stemningspolitisk styring af irrelevante eller flygtige fænomener.

For det andet henter vi næring i nyere feministisk arbejde med affekt og materialitet. Affekt-perspektivet hjælper os med at holde opmærksomheden på det flygtige, på stemninger. Fra materialitets-perspektivet låner vi begrebet om diffraktion, der i stedet for at fokusere på repræsentation eller refleksion (altså spejling) får fat $\mathrm{i}$, hvordan noget afbøjes og splintres for så at samles igen. Det er også her fra, vi kan tale om det fraværende gennem begrebet om hauntologi.

For det tredje er vi inspireret af et greb fra det postkoloniale litterære univers: Da Colson Whitehead (2016) i sin roman lod den underjordiske jernbane ${ }^{2}$ materialisere sig som en faktisk jernbane, der gemmer sig under jorden i gedulgte 'sorte huller', foretog han en brillant kritisk og affirmativ be- vægelse hen imod nutidige race-relationer $\mathrm{i}$ USA. Vi forsøger at bevæge os ad et lignende narrativt spor ved at lade idiomet 'en elefant i rummet' materialisere sig i universitetets gemakker. I forlængelse af dette læser vi ledelsen på bederums-kontroversen gennem George Orwells (1936/2003) novelle Shooting an Elefant.

I bederums-casen foretager hvidheden tre (samtidige) forsvindingsnumre: Den fordufter som den førstehed, der sætter rammerne. Dernæst forsvinder også den ikke-hvides racialiserede andethed. Endelig træder de Andres religion, islam, frem, mens den kristne førstehed tendentielt forsvinder. Tre vægtige forhold bliver flygtige og adresseres hverken i tale eller handling. Alligevel er de virksomt tilstede - som elefanten i rummet - noget, der også har en betydning for, hvordan køn (ikke) adresseres.

Vores begrebsapparat pointerer samtidighed og ikke-linearitet. Det giver os mulighed for fortællermæssigt at bevæge os frem og tilbage i tid og rum. Det markerer vi ved at opbygge artiklen som en række tid/rumkoordinater. Vi begynder i et universitært koordinat, hvor casen udfoldes. Derfra går bevægelserne frem og tilbage $\mathrm{i}$ tid og rum, med jævnlige indskudte besøg i tid/rumkoordinatet kaldet forskerlaboratoriet.

\section{BEGYNDELSEN AF \\ DET 21. ÅHUNDREDE/ \\ DET UNIVERSITÆRE RETRÆTERUM}

Vi starter i et hjørne af den debat, der i 2016/17 rasede (blandt andet i folketinget) om (et statsligt) forbud mod bederum på uddannelsesinstitutioner. Vores nedslag cirkulerer om et indlæg i debatten fra den daværende rektor for Københavns Universitet (herefter rektor og KU), hvor han markerede, at forslaget om et bederumsforbud var udtryk for "stemningspolitik" (Kristiansen og Koch 2017).

Det lokale, der i debatten kaldes bede- 
rum, betegnes på KU's plantegninger og dørskilte ikke som bederum, men som 'retræterum'. På universitets hjemmeside står der følgende om rummet:

"Retræterummet er indrettet med txpper, puder og stearinlys, og på reolen finder du blandt andet Bibelen, Koranen og Toraen. Rummet er åbent for alle, og du er velkommen, når du vil meditere, bede eller bare søge stilhed."

Lokalet blev administreret af universitetets kvindelige studenterprest og i dagligdagen drevet af studerende.

'Retrxte' peger mod en gammel kristen forestilling om refugiet og tilbagetrækning fra det dennesidige for at fordybe sig i og hengive sig til det hinsidige. 'Retræte' har også militære konnotationer og tilkendegiver en tilbagetrækning af soldater og militært materiel. Den type rum findes i lufthavne, virksomheder og uddannelsesinstitutioner og hedder 'reflection lounges', 'inter faith chapels' eller 'multifaith rooms'.

Indlægget af rektor, faldt i en offentlig debat, hvori retræterummet på KU og tilsvarende rum på andre uddannelsesinstitutioner blev betegnet som "reelt islamiske" af bl.a. Dansk Folkepartis Marie Krarup og Socialdemokratiets Mathias Tesfaye. ${ }^{3}$

Krarup havde været på besøg på Københavns Universitetet og fundet retræterummet og ikke mindst nogle Hizb ut-Tahrirflyers i nærheden. Foruden de monoteistiske religioners grundbøger, txpper, puder og stearinlys rummede lokalet ingen politiske eller religiøse tegn eller andet tilbehør såsom relikvier, kors, beklædningsstykker, røgelsespinde eller prædikestole. Krarup, Tesfaye og andre debattører diskuterede forbud og nedlukning fra folketingets talerstol og i diverse medier. Sådanne rum, argumenterede de, fostrede en islamistisk dagsorden og ville blive anvendt af radikaliserede muslimske studerende til at udøve social kontrol over især kvindelige studerende: Bad de nu bønner rettidigt og re- gelmæssigt? Med køn som et af argumenterne måtte den type af rum på universitetet forbydes.

I modsætning til Krarup og Tesfaye afviste rektor, at bederum udgjorde et problem. Bederum er, argumenterede han, ikke for nogle bestemte studerende eller ansatte. Det handler ikke om islam eller muslimer, men om bøn, hvile, meditation og stilhed for alle studerende og ansatte. Politikere og andres ønske om indgreb i brugen af bestemte rum, signalerede for rektor det, han kaldte "stemningspolitik" - og definerede det som en misforstået styring på flygtige detaljer i modsætning til vigtigere og langtrækkende makropolitikker, fx "Danmarks evne til at klare sig i den internationale konkurrence" (Kristiansen og Koch 2017). Rummet er altså for alle, og diskussionen er dermed forfejlet i udgangspunktet. Alligevel er der en stemning, som må italesættes, for dernæst straks at blive afvist af rektor: stemninger skal man ikke styre på, mente altså rektor.

Debatten er blot én i rækken af debatter om lovgivning og statslige forbud rettet mod bestemte beklædningsgenstande, religiøse praksisser, boligområder og opdragelsespraksisser, der trods stadig mere krampagtige forsøg på at formulere på- og forbud universelt, rammer bestemte etniske og religiøse minoriteter i Danmark. Det er i særlig grad minoritetsborgere, hvis kropstegn (såsom hud og hårfarve) og beklædningsstykker læses som tegn på baggrundhistorier vedrørende migration og flugt fra Nordafrika, Mellemøsten og Asien og tilhørsforhold til islam. Men, kunne man spørge, måske især i lyset af at vores empiri udgøres af en debat om bederum, bør vi ikke skelne mellem religion og race?

Spørgsmålet kan besvares på flere måder. Først og fremmest er det vores afsæt, at Europas (og Danmarks) muslimske befolkningsgrupper racialiseres - og dermed også, at race og religion ( og køn) intersekterer. Der foregår racialiseringsprocesser, hvorigennem i øvrigt forskellige befolknings- 
grupper betydningssættes som afgrænsede socio-kulturelle eller raciale/etniske grupper. Når der sluttes direkte fra islam, som religion, til muslimer, og når 'muslim' yderligere sammenføjer en hel række forskellige praksisser, ideer og tegn, så er der snarere tale om racialisering af muslimer, end alene om islamofobi (Meer 2013). Modsætningen i en aktuel dansk kontekst går mellem muslim og dansk, snarere end mellem islam og kristendom, hvor 'muslim' naturligvis artikulerer til Islam, lige som 'dansk' gør det til kristenhed. Dertil kommer - og det er en anden type af svar - at race og religion er biopolitisk og historisk/ontologisk forbundne kar (Weheliye 2014; se også Wynter 2006).

Uddannelsesinstitutioner (især grundskolen) har længe været i centrum for politikker, der skal danne nationens borgere på en særlig måde. Universitetet har dog tidligere været opfattet som en uafhængig og selvstyrende institution. I de senere årtier har der imidlertid været en stadig øget indblanding i interne universitære anliggender, som ligner et forsøg på at gøre det til en statsligt styret kooperation. Trods krav om øget internationalisering er der i styringsformen en udbredt tendens til at anskue universitetet som et nationalt anliggende og konkurrencestatens forlængede arm. Rektors indlæg præges af, at det er hans betingelser for at navigere. Men der dukker også noget andet op. Nemlig afvisning og nedlukning: Bederummet har ingenting at gøre med forskelle, der gør en forskel.

\section{BEGYNDELSEN AF \\ DET 21. ÅRHUNDREDE/ \\ FORSKERLABORATORIET}

I Norden har en dominerende diskurs - i akademia såvel som i andre domæner fastslået vores moderne og exceptionelle anknytning til lighed (som muterer til enshed), demokrati og solidarisk velfærd (Hervik 2001). Amerikansk og engelsk forskning og aktivisme har længe været anderle- des og mere fremtrædende optaget af intersektionalitet og racialisering, også når det gxlder højere uddannelse. Op igennem 1990-erne påviste USA-baserede kritiske racestudier institutionel racisme og farveblindhed, og man analyserede hvordan race interagerede intersektionelt med andre undertrykkelsesakser som køn og klasse (Crenshaw 1991; Ladson-Billings 2010).

I dag er åbenlys racisme og institutionel diskrimination delvist overskrevet af mere usynlige og subtile former for magtudøvelse og (ny)racisme, der til stadighed privilegerer hvidhed (Bonilla-Silva 2006) og opretholder en 'epistemology of ignorance' (Mills 2007).

Vores metodologiske eksperiment trækker på, men forskyder også disse selvfølgelighedsforstyrrende forskningstraditioner ved at nærme sig race gennem et vokabular om stemning. Stemninger er affektive og atmosfæriske. De er 'structures of feeling' (Williams 1977), der stemmer situationer, rum og relationer. Sarah Ahmed argumenterer for, at diversitetsarbejde er stemningsarbejde, og beskriver den kropslige erfaring af at ankomme i et rum som den raciale den ikke-hvide - anden, som både pålægges diversitetsarbejdet og er den, der må (af)stemme sig (Ahmed 2012; 2014). Det betyder, at affektive atmosfærer knytter sig til og (gen)etablerer en differentieret kapacitet til at afficere og blive afficeret (Anderson 2016).

I første omgang kan idiomet elefanten $i$ rummet anskues som en repræsentation. En repræsentation af fravær; af det ikke repræsentationsbare. For vores forehavende forekommer det dog mere frugtbart at knytte idiomet til netop stemningsbegrebet. Elefanten i rummet gør sig gældende som en omfattende følelsesstruktur; det massive, men alligevel ikke grib-bare dyr markerer en kollektiv stemning, der rammer og omslutter, toner og filtrer sig ind i det, der foregår. Den angår ubehag. Det mærkes og registreres kropsligt, at elefanten er der. Og det mærkes af alle, men jf. den differentie- 
rede kapacitet til at afficere og blive afficeret, er effekten af at mærke elefanten forskellig.

For hvidheden - for den kapacitet, som har 'the upper hand' - bliver stemningen ubekvem og akavet, og udløser vægring, undgåelse og undvigelse. Måske for at undgå pinagtigheder, eller for at undgå, at man selv eller andre skal føle sig ubehageligt til mode. Elefanter i rum handler om stemninger affødt af sociale tabuer, der er særdeles affektivt ladede, og hvor tabuet, hvis det udsættes for nyfigen interesse, kan eksplodere, hvorfor det for en hver pris må undgås, ja måske endog forebygges og derfor forgribes. Det anticipatoriske element $\mathrm{g} \varnothing \mathrm{r}$ elefanten i rummet til en temporal figur, der griber ud efter det virtuelle (det der kunne komme) og nu og her forsøge at tæmme det. Ikke så mærkeligt, at rektor på KU søger at afmontere stemningspolitik.

Før vi går længere ind i elefantarkivet, må vi en tur omkring den i queerfeministiske og posthumane kredse velbeskrevne metodologi diffraktion (Barad 2007; 2014; Haraway 1992; 1997). Diffraktion betyder afbøjning. Som Karen Barad påpeger, kan diffraktion forstås som såvel et fænomen som en metodologi - en 'onto-epistemologi' - der tillader at sætte empiri og forskningsspørgsmål på nye (queerfeministiske og kvantefysisk inspirerede) måder. Ordet diffraktion hidrører fra det latinske 'diffrangere', som betyder 'fra' (dis) og 'brække’ (frangere), altså at brække noget i stykker. Man kan tænke på luft- og lydbølger "which upon encountering an obstacle breaks up and moves outwards in different directions" (Barad 2014, 171). Der tilsættes intet nyt, men noget nyt ser alligevel ud til at blive til i diffraktionen (ibid., 168). Diffraktion betyder altså at brække/bryde i stykker og det medfører, at brudene transformeres til en række nye sammensatheder. Diffraktion beskrives ofte som en processuel 'cutting-together-apart', altså at noget i en og samme bevægelse brydes, splintres og sammensættes. Det er en interferens, som ligner de brydninger og intra-aktioner, der opstår, når vandbølger brydes med hinanden eller i mødet med en forhindring; et 'wave-cut', der har spatiale, temporale og energetiske effekter (Haraway 1992; Juelskjær 2010).

Diffraktion har efter Foucaults brug af ordet 'diffraktionspunkt' om det sted, hvor diskursen indebærer såvel interferens som association (Foucault 1982), og efter Haraways kobling af diffraktion med Min-ha's begreb om de 'u/passende Andre' (Haraway 1992; 1997; Minh-ha 1986/87), fået en gevaldig renæssance gennem Barads videreudvikling og kobling til Derridas begreb om hauntologi, dvs. viden om dét, der hjemsøger (Barad 2007; 2010; 2014).

Som Barad (2014) skriver, kan der fra ordet diffraktion rulles tilbage til forskellige genealogier. Hun arbejder sig selv igennem disciplinen fysik (især Grimaldi, Young og Niels Bohr), og videre ind i feministiske studier af især Donna Haraway og postkolonial feminisme (Minh-ha 1986/87; Anzaldúa 1987/2012), der gentænker relationalitet, og hvor forskelle figureres som en 'difference within'. Barad (2014) fremhæver, at diffraktion ikke handler om enhver forskel, men om de forskelle, der gør en forskel. For at understrege forskellen racialisering tilsætter vi elefanten i rummet. Elefanten i rummet er et idiom, en talemåde, men samtidig en temporal figur. Den handler om stemning. Det affektivt flygtige. Den energi, der frembringes i tid og rum.

Men hvordan, kan nogle spørge, er det så, at I mere pracist kobler race og racialisering til debatten om bederum? Ét svar er, at vi har valgt ikke at ignorere det. Selvom vi som hvide kvinder faktisk kunne lade det være ubemærket. I stedet for at investere vores kraft i det hårde arbejde i form af iterative omskrivninger, genfortællinger, ommøbleringer, omstruktureringer, omorganiseringer osv.), der er forbundet med at ignorere (Swan 2010), forsøger vi at respondere på det. Vi stoler på den følelsesstruk- 
tur, vi mærker gennem vores kropslige og historiske indlejrethed. Ligesom vi stoler på vores teoretiske begreber og deres historisk informerede forskningslandskaber: Elefanten er der, og er der ikke. Den bemærkes. Tydeligt af nogle og nærmest ikke af andre. Den lades ubemærket af nogle og kan ikke undgås af andre.

\section{BEGYNDELSEN AF}

DET 20. ÅRHUNDREDE/

KOLONISERET VERDEN

Det koloniale arkiv vrimler med elefanter. Elefanten er fast inventar i europæiske billeder af imperiet og koloniale fantasier. Børn er siden begyndelsen af det 20. århundrede blevet introduceret til imperiets fortræffeligheder i historierne om babyelefanten Barbar (fra 1931) og i Kiplings historie om, hvordan elefanten fik sin snabel (1902). I Harald H. Lunds børnesang Elefantens vuggevise fra 1947 mødes elefanten og racismen i den oprindelige linje "I morgen får du en niggerdreng, og ham kan du bruge som rangle".

Elefanterne rejser i selskab med imperial melankoli i Agatha Christies og E.M. Fosters bøger og manifesterer sig emblematisk i Carlsberg-grundens imposante elefantport, og i den i fysisk forstand mindre elefantorden. Elefanten er altså et tilbagevendende tema i europxiske forestillinger om imperiet. Og når elefanten bevæger sig ind i rummet, knytter denne arv sig til tabuet; til det, der skal undgås eller omgås.

På den måde er det ikke så besynderligt at forskyde elefanten ind i det hvide universitets bederum og den ledelse, det bliver udsat for. Vi argumenterer for, at idiomets genealogi knytter an til kolonialisme, og at det igennem den genealogi bliver muligt at se idiomet som udspændt mellem en foregribelse af det potentielle; dét, der kan ske, og det fortidige; dét, der så at sige stemmer foregribelsen.

Diffraktionsmetodologien peger alment på processer, hvori forskelle kommer til at gøre en forskel. Elefant-idiomet gennemtvinger i sin anknytning til den koloniale arv og i kombination med diffraktionsmetodologien en 'dobbelt op' opmærksomhed på forskelle, der gør en racial forskel.

I George Orwells essay Shooting an Elephant (1936/2003) fortælles om en begivenhed, der fandt sted, da fortælleren arbejdede for det imperiale politi i Burma. Han kaldes ud til en tam elefant, der er gået amok og bevæbnet med sin riffel, drager han ud i byens fattige kvarterer for at undersøge elefantens færd. Efter først at have mistænkt det for at være et svindelnummer for at prøve ham af, opdager han, at elefanten har trampet et menneske ihjel. Han får med nogen tøven fat i sin riffel, der egentlig ikke er til elefantskydning, og går med en stor menneskemængde på elefantjagt. Elefanten finder han, mens den nu helt fredeligt står og græsser som en anden ko. Så hvad nu? Skal han skyde eller ej? Stemt og drevet af menneskemængdens forventning om eksekvering, skyder han meget mod sin vilje elefanten.

Essayet indeholder eksemplarisk alle 'elefanten i rummets' elementer. Derfor er det dén fortælling, vi søsætter - ikke for at bruge de beskrevne racialiserede følelsesstrukturer i novellen som en afspejling af bederumsdebatten eller rektors håndtering heraf, men derimod som en diffraktionsmulighed. Hvis vi læser episoderne fra den danske velfærdskontekst igennem novellen, hvilke elementer dukker så op? Hvad samler sig?

\section{BEGYNDELSEN AF}

DET 21. ÅHUNDREDE/

RETRÆTERUMMET, NORDISK

VELFÆRDSKONTEKST

Retræterummet er et enkelt lokale blandt hundreder af lokaler. Et lille kammer i det store universitet etableret med henblik på en pause, et kontemplativt afbræk i dagen. Men nu en forstyrrelse. Det larmer og støjer. Retræterummet muterer fra stille 
sted til larmerum. Et alarmerende rum. På ingen måde et helle, men nu et terræn, hvor elefanten tramper og trompeterer rundt. En prøvelse for rektor, som den var det for fortælleren i Orwells novelle.

Igennem længere tid har universitetsøkonomi været et anliggende for statens regulering. Men med diskussionen om bederummet åbnes der for, at også dets bygninger og arkitektur skal styres oppefra. Brugen af campus (som oprindeligt betyder 'åben plads') udsættes for national politisk styring i detaljen. Ikke gennem incitamenter eller besluttet af universitetets ledelse, ansatte og studerende, men af staten og igennem forbud. Balladen om retræterummet minder om, at universitetets selvstændighed er under angreb, og har været det længe.

Når retræterummet i debatten omdøbes til 'bederum', der skal forbydes, understreges det, at universitetet er blevet et nationalt anliggende: en dansk dannelsesinstitution. I første moment for at beskytte kvindelige studerende mod at blive kontrolleret i deres bedepraksis: En beskyttelse mod brune mænd varetaget af hvide (Spivak 1988). I næste moment bliver beskyttelsen af disse kvindelige studerende udtryk for varetagelse af nationens ve og vel. Retræterummet bliver en affektivt ladet trussel mod en større og mere omfattende helhed. Rummet kan ikke længere tillades at være minoritetens helle, fordi dets eksistens bliver ensbetydende med en trussel mod majoritetssamfundet.

Paradoksalt nok foregår den nationalisering (og dermed en mindre højlydt, men dog tilstedeværende genkristning) af universitetet samtidig med, at det forudsættes at opføre sig som en stor international virksomhed, der skal klare sig i konkurrencen på en mangfoldig planet. Det er den makro-politik, rektor gerne vil bekende sig til. Han forsøger at dxmpe larmen ved at sige, at rummet er for alle. Men universitetets terræn er allerede besat og beboet på en bestemt måde; og måske er det at opfatte og definere institutionen som inkluderende og åben kun muligt, fordi den er åben for rektor selv: "The built and arranged space through which we navigate our lives tends to offer fits to majority bodies and create misfits with minority forms of embodiment" (Ahmed 2017, 15).

Retræterummet er der, fordi en bestemt gruppe studerende har ønsket det. Der er ingen restriktioner knyttet til hvem, der må bruge det. Men ikke alle bruger det, og for nogle af brugerne bliver det, som debatten viser, nu forklaringskrævende. På grund af deres brug, bliver rummet truende. Dermed ender nogle af rummets brugere med at blive forvist - de er paradoksalt nok malplacerede. I intra-aktionens skygge spøger det: Snarere end en radikalisering af de, der bruger retræterummet, er der ved at fremvokse en radikaliseret hvidhed, som ikke vil stå ved siden af det andet eller rumme det. Men hvidheden tales ikke højt frem og det gør det kristne heller ikke. Dét, der siges højt, er, at problemet er islam og måske især muslimske mænd.

\section{BEGYNDELSEN AF}

DET 21. ÅRUNDREDE/

ET POSTKOLONIALT EUROPA

I forhold til den koloniale arv og de raciale strukturer, som formede og fortsat former verden, lider kolonisatorernes arvtagere af amnesi, påpeger Stuart Hall (2000). Gloria Wekker (2016) beskriver, hvordan 'hvid uskyld' spiller en central rolle i hollandsk, akademisk vidensproduktion og selvforståelse. Hun undrer sig over, hvordan en nation, der har været imperial magt i 400 år forestiller sig en samtid uden spor af raciale ordninger. Og over hvordan samme nation i nyere migrationssammenhænge samtidig fremstiller sig selv som offer snarere end gerningsmand. Wekker analyserer sig frem til, at hvid uskyld står på et kristent religiøst fundament og bliver artikuleret med nationens nutidige lidenhed og de kvindelige konnotationer, den smykker sig med. 
Wekkers analyse er en historisk og stedslig specifik analyse af Holland. Man kunne alligevel tro, hun skrev om Danmark. Men Danmark og Holland er ikke det samme. For eksempel er den hollandske institutionalisering af det kristne religiøse grundlag $i$ adskilte søjler anderledes end den danske statskirke. Kolonialisme er en delt global arv, men i tilnærmelsen til konkrete hændelser og konkrete empiriske analyser er det nødvendigt at zoome ind på de specifikke elementer i arven og dens forvaltning.

Det ser ud til, at den danske, hvide uskyld efterhånden kræver hårdt arbejde for at udviske, glemme og ignorere. En jernvilje til ikke at ville vide. Hvid uskyld kan overordnet forstås i sammenhæng med udviklingen af socialvidenskaberne, og en økonomisk og historisk videnskabelig tænkning, der adskiller metropolens historie fra koloniernes (Wekker 2016). Globalisering og internationalisering anskues som noget, der er ved at ske, ikke noget, der er hele modernitetens forudsætning. Universitetet, forstået som rammen om den institutionaliserede videnskab, er altså - trods det efterhånden hullede selvstyre - vævet sammen med såvel kristen tradition som kolonial, imperial magt; dertil kommer, som vi allerede har været inde på, nutidig new public management rundet af nationale interesser. Jo, måske er nationen lille, kristen og kvindeligt konnoteret, og ja, KU er meget mere end en institution med en kolonial arv. Men når vi læser sagen igennem Orwells Shooting an Elefant dykker vi ned i de sorte huller, og set her igennem spøger noget i rektors intervention, der rækker langt ud over ham selv og langt ud over uskyld, ignorering og uvidenhed.

\section{BEGYNDELSEN AF \\ DET 20. ÅRHUNDREDE/ \\ KOLONISERET BURMA}

I Orwells novelle peges der på dét, der vækker elefanten i rummet. Essayet foregriber på mange måder en senere postkolonial skrivning. Især er der slægtskab med Homi Bhabhas (2004) opfattelse af kolonial magt og autoritet, hvor relationen mellem kolonisator og kolonialiseret er ambivalent og for kolonisatoren gennemkrydset af ængstelighed tenderende til en stemning af angst. Orwells fortæller udsættes for had, bitterhed og fornærmelser, som går ham frygteligt på: "I was stuck between my hatred of the empire I served and my rage against the evil-spirited little beasts who tried to make my job impossible" (Orwell 2003, 31).

Trods sin kritik kan Orwells fortæller ikke (be)gribe de kolonialiseredes følelser og blive en del af dem; han kan ikke undslippe kolonisatorens position. Den stemning, der $i$ episoden med elefanten suger ham ind, afficerer ham, og han fanges $i$ en affektiv spænding, som han - ængsteligt og modvilligt - tvinges til at styre på; og i det øjeblik han indser, at han er nødt til at skyde elefanten, begriber han:

the hollowness, the futility of the white man's dominion in the East. Here was I, the white man with his gun, standing in front of an unarmed native crowd - seemingly the leading actor in the piece; but in reality I was only an absurd puppet pushed to and fro by the will of those yellow faces behind. (...) A sahib has got to act like a sahib; he has got to appear resolute, to know his own mind and do definite things. To come all that way, rifle in hand, with two thousand people marching at my heels, and then to trail feebly away, having done nothing - no, that was impossible. The crowd would laugh at me. And my whole life, every white man's life in the East, was one long struggle not to be laughed at. (Orwell 2003, 36-37)

Orwells fortæller kan altså ikke undslippe sin hvidhed og den koloniale magtposition, hvidhed klæber til. Ej heller den position i den racialiserede struktur, han er sat til at styre på. Det er stemningen, der indfanger og driver ham til noget, han samtidig mær- 
ker sin egen modvilje i forhold til. Elefanten udgør ikke årsagen til hans humør, men den intensiverer situationen: Et imperialt halv-objekt, der udstråler den ængstelighed og angst, der binder kolonisatoren til den koloniserede. Elefanten er måske nok imperial, men den er ikke imperiet. Den er både den anden og selvet - den er både angst og tabu. Orwell kalder det en lille hændelse, men det er samtidig netop den episode, der skubber ham derud, hvor hullerne i den ontologi han lever i og med trænger sig på. Den vrænger af ham, skubber hans egen position i den imperiale struktur i forgrunden. Den gør ham til den 'sahib', han ikke vil være og samtidig ikke kan undslippe. Og imens truer det værste: han er (måske) til grin. Det er noget af et hul.

\section{BEGYNDELSEN AF}

DET 21. ÅRHUNDREDE/

'UNIVERSITETET/

POSTKOLONIAL VELFÆRDSKONTEKST

Krarup og Tesfaye samler angsten op og sender den i cirkulation i debatten. De kræver universitetet transformeret til et nationalt kontrolleret og renset helle for hvide. En retræte til et sted, hvorfra hvid uskyld kan udleves uden at blive forstyrret af den larm, der siver ud af bederummet. De skyder gerne elefanten, kunne man sige. Så er den der jo ikke længere. Og eftersom retræterummet befinder sig et andet sted, så er det ikke dem, der bliver til grin. Rektor tager form af den 'sahib' som må vare sig. Og som også gør noget andet. Han forsøger sig med den salomoniske løsning: rummet er for alle. Dermed maner han i en vis forstand elefanten ind i rummet igen: lad den nu græsse fredeligt derinde. Egentlig er den der jo ikke. Dog er døren blevet tilstrækkeligt åben til, at der skal et dobbeltgreb til: Et greb, der ikke blot ignorerer, men metakommunikerer og minimerer: Stemninger, det flygtige og mikrodetaljerne er uvæsentlige og skygger for det, der er væsentligt.
Gennem dét greb gør rektor - som Orwells fortæller, om end på en anden måde faktisk et forsøg på at lede på stemningen. Det er nemlig her i forsøget på at holde den gode stemning ved lige gennem at negligere de forskelle, der gør en forskel, at der styres på den, og at der opstår en (stemnings)politik. Diffrakteret igennem 'elefanten' konvergerer og samler rektors intervention sig til et omvendt diversitetsindgreb, der kommer til at fastholde entydigheden, gennem benægtelse af forskellene. Modsat et diversitetsarbejde, der forsøger at transformere institutioner ved at åbne dem op for andre end de, den i første omgang var bygget til (Ahmed 2017).

Som Orwells fortæller kan heller ikke rektor undslippe sin position. Interventionen kan ikke først og fremmest tilskrives ham som individ. Den er et udløb af den struktur, han skal håndtere; de betingelser for at styre, han er underlagt. Interventionen er ikke ekstremistisk. Rektor giver på ingen måde udtryk for, at tilstedeværelsen af muslimer i retræterummet er en trussel mod universitetet og dets selvfølgeligheder. Faktisk ser det ud til, at interventionen sigter mod at holde ekstremisme i ave. Men paradoksalt nok făr han ikke dxmmet op for den, fordi hans stemningspolitik fortsætter en majorisering og afvisning af, at der også kunne være noget særligt i spil. Nogle særlige behov, særlige måder at bruge rummet på. Han gemmer sig i den universalisering - 'Man's project' (Wynter 2006), som retræterummet jo faktisk er et opgør med. Måske fordi han forudser en (endnu) dårlig(ere) stemning, hvis elefanten slipper ud gennem dørsprækken. En stemning, der kan få materielle effekter i form af nedskårne bevillinger og aflysning af velvilje fra landets regerende partier. Dét er jo at blive grundigt til grin.

Udviskningen af forskelle er på mange måder en hædret skandinavisk håndteringsstrategi. Vi skal være lige. Og derfor må vi også være ens. Men så mangler noget. Enshedsfordringer skaber en hullet ontologi. 
Splintrer og samler vi rektors indlæg gennem elefanten i rummet bliver racialiseringen/afracialiseringen ved med at komme tilbage og på forskellig vis tone stemninger. Der er intet nyt, men det er alligevel nye samstillinger, der brager sammen i nye affekter og giver nye effekter. En akkompagnerende og trompeterende elefant, der sanseligt perciperes af alle tilstedeværende, men registreres uens af uens kroppe.

\section{BEGYNDELSEN AF}

\section{DET 21. ÅHUNDREDE/ FORSKERLABORATORIET}

Artiklens ambition var at oparbejde en metodologi, et greb om noget, der ikke lader sig gribe så let (nemlig racialisering og hvidhed som stemning $\mathrm{i}$ en nordisk velfærdskontekst), samtidig med at dette er nær ved umuligt, fordi det netop er atmosfærisk og omskifteligt.

Den idiomatiske diffraktion med Shooting an Elefant åbnede bederummet og skabte interferensmønstre, hvorfra lyset i skyggerne (Barad 2010) kunne undersøges. Men den idiomatiske diffraktion kan ikke bruges som en afspejling af stemninger i empirien. Det er ikke et en-til-en-affotografering af genstandsfeltet. Det ville nemlig være en fastholdelse af den koloniserende logik, hvor forskel altid betyder forskellig fra og væk fra noget allerede fastsat. Snarere betyder dét at undersøge og læse diffraktivt gennem et idiom at følge og affirmere de tendenser, der opstår i sammenfiltringen af idiomet og empirien, mens materialet brækkes fra hinanden. På den måde kan idiomatisk diffraktion metodologisk understøtte en affirmativ kritik af en hullet ontologi. Det betyder, at diffraktion ikke er en måde, hvorpå forskeren kan 'undslippe' sin hvidhed, men metodologien kan forstyrre forskerens allerede etablerede kortlægninger.

Diffraktionsbegrebet er dog ikke 'uskyldigt'. Der har været en anseelig aftapning i feministiske analyser. Men til trods for, at diffraktion drejer sig om mønstre og effek- ter af (mønstre) vedrørende forskelle og sammehed, er der få studier af race og racialisering.

I Diffracting diffraction trævler Barad (2014) diffraktionsbegrebet op gennem genealogiske tråde tilbage til Trinh Min-ha, Donna Haraway og Gloria Anzaluda, og dermed også til race og kolonialisme. Det har været centralt for vores forehavende, fordi den tråd videreformidler feministiske indsigter om samtidige forskelle og sammeheder og (teoretisk) taler imod absolutter og for simultane dis/kontinuiteter. Men race og racialisering antydes kun i Barads tekst, og eksisterer mest som et epistemologisk back-drop, der tenderer til at forsvinde igen: Race som ontologi bliver flygtigt i Barads tekst.

Samtidig er det queerfeministiske diffraktionsbegreb relateret til fysikken og præget af en californisk kontekst, der indeholder sit særlige 'take' på postkolonialisme og multikulturalisme. Og det er noget andet end nordisk postkolonial tavshedskultur med ideer om egen ekceptionalitet og om lighed knyttet til monokulturelle imperativer. Som Barad også selv ville påpege, er det ikke nok med en generisk universal-skabelon. Der må tages højde for empiriske specificiteter, og det kalder på begrebslig justering. Derfor inviterede vi idiomet ind.

I Modest_Witness@Second_Millenium.FemaleMan_Meets_OncoMouse beskæftiger Haraway (1997) sig med andre arter og mere-end-mennesker og her driver genstandsfeltet en mere eksplicit race-bekymring frem. Race er et slingrende, bævrende fænomen, der på en gang er manifest og illusorisk (ibid.) Det jager os, selvom vi fornægter dets eksistens. Med den 'wor(l)ding' leder Haraway vores tanker i retning af Derrida-inspirerede hauntologier, dvs. spøgelsesontologier, der kredser om den fraværende tilstedeværelse og det fraværendes medkonstituering af det præsente (Derrida 1993/2006). Det fører videre (og tilbage) til Barad (2010), der på overbevisende vis har arbejdet med netop Derridas 
hauntologi som diffraktiv metodologi for at fremlæse hullede, oversete, glemte ontologier og som kilder til det 'unheimliche'.

Men hauntologi har sine politiske og etiske komplikationer $\mathrm{i}$ forhold til en racial problematik. For spøgelsesjagten ender som plottet i romanen The Human Stain (Roth 2000) - med ordet 'spook', som vi i dag kun kender og oversætter som 'spøgelse', men som i 1940-erne anvendtes om en sort hud svær at skelne i mørket. Så jo, man kunne læse race som et spøgelsesfænomen, men der er en alvorlig mere-end-bevidst fare (som romanen så finurligt afslører) for at gøre den raciale anden til spøgelset, snarere end at vise race som en relation, der hjemsøger alle, men registreres og betyder noget forskelligt.

Elefant-idiomet er et etisk holdbart alternativ til spøgelserne. Snarere end at antyde minorisering og majorisering som et socialt kategorialt anliggende, hvilket der er tendens til hos Barad, træeder netop magt, minorisering og majorisering knyttet til race frem. Og det er afgørende, når man er optaget af diversitetsledelse og intersektionalitetstilgange: Vi har brug for greb, der forpligter os på at følge racial onto-normativitet - måske endda før, men i hvert fald samtidig med, at vi siger køn i Akademia.

\section{NOTER}

1. Vi skriver 'oprindelige befolkninger' som dansk oversættelse af 'indigenous people' uden at være begejstrede for de konnotationer, der ligger i oversættelsen.

2. Underground Railroad refererer til et netværk af ruter, safe houses og personer, som (fra begyndelsen af 1800-tallet) hjalp afrikansk amerikanere med at flygte fra deres slavetilværelse i Sydstaterne. Jernbane-metaforen var afsæt for et 'hemmeligt' sprog, som anvendtes om personer og stadier i flugten.

3. Se bl.a.: Berlingske Tidende 20. 2.2017; Politiken 21. 2.2017; Uniavisen 21. 2.2017; Kristeligt Dagblad 21.2.2017; Altinget 21.2.2017; Uniavisen 3.3.2017.

\section{LITTERATUR}

- Ahmed, S. 2006. Queer Phenomenology. Orientations, Objects, Others. Durham and London: Duke University Press.

- Ahmed, S. 2012. On being included: Racism and Diversity in Institutional Life. Durham NC: Duke University Press.

- Ahmed, S. 2014. Not in The Mood. New Formations. 82(1), 13-28.

- Ahmed, S. 2017. Institutional As Usual: Diversity Work as Data Collection. Lecture at Barnard College, October 16, 2017, and Princeton University, October 17, 2017.

- Anderson, B. 2016. Encountering Affect. Capacitites, Apparatuses, Conditions. London \& New York: Routledge.

- Andreassen, R. and Myong, L. 2017. Race, Gender, and Researcher Positionality Analysed

Through Memory Work. Nordic Journal of Migration Research, 7(2), 97-104. DOI:

https://doi.org/10.1515/njmr-2017-0011

- Anthias, F. and Yuval-Davies, N. 1992. Racialized boundaries. race. nation, gender, colour and class and the antiracist struggle. London: Routledge.

- Anzaldúa, G. 1987/2012. Borderlands/La

Fronera: The New Mestiza. San Francisco: Aunt Lute Books.

- Barad, K. 2007. Meeting the Universe Halfway: Quantum Physics and the Entanglement of Matter and Meaning. Durham: Duke University Press. - Barad, K. 2010. Quantum entanglements and Hauntological Relations. Derrida Today. 3(2), 240-268. DOI: 10.3366/E1754850010000813

- Barad, K. 2014. Diffracting Diffraction. Cutting Together-Apart. Parallax. 20(3), 168-187. DOI: https://doi.org/10.1080/13534645.2014.9276 23

- Bhabha, H. 2004. The Location of Culture. London: Routledge Classics.

- Bonilla-Silva, E. 2006. Racism without racists: Color-blind racism and the persistence of racial inequality in the United States. New York: Rowman \& Littlefield.

Brah, A. and Phoenix, A. 2004. 'Ain't I a Woman?' Revisiting Intersectionality. Journal of International Women Studies. 5(3), 75-86.

. Collins, P. H. 1998. It's all in the Family: Intersection of Gender, Race, and Nation. Hypathia. 13(3), 62-82.

. Crenshaw, K. W. 1991. Mapping the Margins: Intersectionality, Identity Politics, and Violence Against Women of Color. Stanford Law Review. 43 (6), 1241-1299. DOI: 10.2307/1229039 - Derrida, J. 1993/2006. Specters of Marx. The 
State of the Debt, the Work of Mourning and the New International. New York: Routledge Classics. - Frankenberg, R. 1993. White Women, Race Matters: The Social Construction of Whiteness. Minneapolis: The University of Minnesota Press. - Foucault, M. 1982. The Archaeology of Knowledge. London: Vintage.

. Hall, S. 2000. The Multicultural Question. In: Hesse, B. ed. Un/Settled Multiculturalisms: Diasporas, Entanglements, Transruptions. London: ZED Press, 209-240

- Haraway, D. 1992. The Promises of Monsters: A Regenerative Politics of Inappropriate/d Others. In: Grossberg, L., Nelson, C. and Treichler, P.A. eds. Cultural Studies. New York: Routledge.

. Haraway, D. 1997. Modest_Witness@Second_Millenium.FemaleMan_Meets_OncoMouse. New York: Routledge.

- Hervik, P. 2001. Lighedens diskrimination: Den danske farveblindhed i det flerkulturelle samfund. Nordic Journal of Human Rights. 2, 41-53.

- hooks, b. 1981. Ain't I a woman? Black women and feminism. Boston: South End Press.

- Højgaard, L. og Søndergaard, D.M. red. 2003. Akademisk tilblivelse. Akademia og dens kønnede befolkning. København: Akademisk Forlag.

· Juelskjær, M. 2010. Kvantefysiske subjekter. Nordiske Udkast. Tidsskrift for kritisk samfundsforskning. 38(1-2), 58-74.

- Kristiansen, C. L. og Koch, T. Ø. 2017, 24. februar. Politikerne gumler på de gale gåder. Politiken.

- Ladson-Billings, G. 2010. Just what is critical race theory and what's it doing in a nice field like education? International Journal of Qualitative Studies in Education. 11(7), 7-24. DOI:

$10.1080 / 095183998236863$

- Lorde, A. 1984/2007. Sister Outsider. Essays and Speeches by Audre Lorde. Berkeley: Crossing Press.

- Lykke, N. 2010. Feminist Studies. A Guide to Intersectional Theory Metholodogy and Writing. New York \& London: Routledge.

- Meer, N. 2013. Racialization and religion: race, culture and difference in the study of antisemitism and Islamophobia. Ethnic and Racial Studies. 36(3), 385-398. DOI:

https://doi.org/10.1080/01419870.2013.7343 92

- Mills, C. 2007. White Ignorance. In: Sullivan, S. and N. Tuana, N. eds. Race and Epistemologies of Ignorance. Albana, NY: SUNY Press, 26-31. - Minh-ha, T. T. 1986/87. Introduction (SI on "She, The Inappropriate/d Other"). Discourse: Berkeley journal for theoretical studies in media and culture. 8, 3-10.
Myong, L. 2009. Adopteret-fortellinger om transnational og racialiseret tilblivelse. PhD-dissertation. København: Danish School of Education, Aarhus Universitet.

- Mørck, Y. 1998. Bindestregsdanskere. Frederiksberg: Samfundslitteratur.

. Orwell, G. 2003. Shooting an Elephant: And Other Essays. London: Penguin.

- Oyewumi, O. 2007. Kønnets begrebliggørelse:

Det eurocentriske grundlag for feministiske negreber og udfordringen fra afrikanske epistemologier. I: Søndergaard, D.M. ed. Feministiske tenkere. København: Hans Reitzels Forlag, 252-263.

- Roth, P. 2000. The Human Stain. London: Vintage.

- Saldanha, A. 2006. Reontologising race: the machinic geography of phenotype. Environment and Planning D: Society and Space. 24, 9-2. DOI: https://doi.org/10.1068/d6lj

- Seerup, T. J. 2017, 25. jan. Søren Espersen: Kvindebevægelsen er død i Danmark, når I overser dette problem. Nyheder.TV2.dk.

- Spivak, G. C. 1988. Can the Subaltern Speak? In: Nelson, I.C. and Grossberg, L. eds. Marxism and the Interpretation of Culture. Basingstoke: Mcmillan Education, 271-313

- Spillers, H.J. 2003. Mama’s Baby, Papa's Maybe. An American Grammar Book. Diacritics, 17(2), 65-81

- Staunæs, D. 2003. Where have all the subjects gone? Bringing together subjectification and intersectionality. NORA. Nordic Journal of Feminist and Gender Studies. 11(2), 101-110.

DOI:

https://doi.org/10.1080/08038740310002950

- Staunæs, D. og Søndergaard, D. M. 2006. Intersektionalitet: udsat for teoretisk justering. Kvinder, Køn \& Forskning. 15(2/3), 43-56. DOI: https://doi.org/10.7146/kkf.v0i2-3.28086

- Swan, E. 2010. States of White Ignorance, and Audit Masculinity in English Higher Education. Social Politics. 17(4), 477-506. DOI: https://doi.org/10.1093/sp/jxq016 - Søndergaard, D. M. 2005. Making Sense of Gender, Age, Power and Disciplinary Position: Intersecting Discourses in the Academy. Feminism of Psychology 15(2), 189-208. DOI: https://doi.org/10.1177/0959353505051728 - Weheliye, A. G. 2014. Habeas Viscus. Racializing Assemblages, Biopolitics, and Black Feminist Theories of the Human. Durham \& London: Duke University Press.

- Wekker, G. 2016. White innocence: Paradoxes of colonialism and race. Durham \& London: Duke University Press. 
. Williams, R. 1977. Marxism and Literature. Oxford University Press: Oxford.

- Whitehead, C. 2016. Den underjordiske jernbane. København: J/P Politikens Forlag.

- Wynter, S. 2006. On How We Mistook the Map for the Territory and Re-imprisoned Ourselves in our Unbearable Wrongness of Being, of Désêtre: Black Studies toward the Human Project. In: L. R. Gordon, L.R. and J. A. Gordon, J.A. eds. Not Only the Master's Tools: African-American Studies in Theory and Practice. Boulder, CO: Paradigm, 107169. 